CENTRE

for

ECONOMIC PERFORMANCE

DISCUSSION PAPER NO. 338

MARCH 1997

LABOUR MARKET POLICY AND THE REALLOCATION OF LABOUR ACROSS SECTORS

R. JACKMAN and C. PAUNA 


\begin{abstract}
This paper investigates the extent of labour market reallocation across broad industrial sectors in the transition economies of Eastern Europe since 1989. It offers various measures of the magnitude of labour misallocation and of the speed and efficiency of reallocation during the first half of the 1980s. It compares the performance of the economies of Eastern Europe with one another and with two Southern European economies, Greece and Portugal, which have also been experiencing substantial economic change. Contrary to much a priori theorising, the paper finds no correlation between unemployment and the speed or effectiveness of labour market reallocation. The authors argue that the analysis in the paper strengthens the case for an active as against a passive approach to labour market policy.
\end{abstract}

This paper was produced as part of the Emerging Markets Programme 


\section{LABOUR MARKET POLICY AND THE REALLOCATION}

OF LABOUR ACROSS SECTORS

R. JACKMAN and C. PAUNA 


\author{
Published by \\ Centre for Economic Performance \\ London School of Economics and Political Science \\ Houghton Street \\ London WC2A 2AE \\ (C) R. JACKMAN and C. PAUNA \\ ISBN $085328377 \mathrm{X}$
}




\section{LABOUR MARKET POLICY AND THE REALLOCATION OF LABOUR ACROSS SECTORS \\ R. JACKMAN and C. PAUNA}

Page

Introduction

1

1. The Reallocation of Labour Across Sectors

2. Labour Reallocation and Aggregate Unemployment 9

3. Employment Decisions of State Firms

4. Policy

Data Appendix

21

Tables

23

Figure 1

39

References

40

The Centre for Economic Performance is financed by the Economic 
and Social Research Council. 


\section{ACKNOWLEDGEMENTS}

This paper was prepared for the OECD Colloquium on "Economic Transformation and Development of Central and Eastern Europe: What Lessons from the 1990s?", Paris, 29-30 May, 1996.

Richard Jackman is at the Centre for Economic Performance, London School of Economics and Catalin Pauna is at Queen Mary and Westfield College. 


\title{
LABOUR MARKET POLICY AND THE REALLOCATION OF LABOUR ACROSS SECTORS
}

\author{
R. JACKMAN and C. PAUNA
}

\section{INTRODUCTION}

This paper is concerned with the process of reallocation of labour across broad industrial sectors. There are two main reasons for being particularly interested in this issue. First, one of the most conspicuous features of the pre-reform labour market of the formerly socialist economies, as compared to that of market economies, is the very different structure of employment across broad industrial sectors. The large-scale movement of labour from agriculture and manufacturing industry into the service sector is evidently one of the major tasks of economic restructuring.

Second, the reallocation of labour is a task that must fall upon the "external" labour market. It can be achieved only by the physical mobility of workers who leave one enterprise and find work in another. It is thus the dimension of restructuring in which any deficiencies in the workings of the labour market, such as impediments to labour mobility or poorly developed employment exchanges, are likely to have the most severe effect. By contrast, at least part, and possibly a large part, of the adjustment to new technology or commercial business practices involves restructuring within the enterprise, in the sense of introducing new working practices or organisational structures within firms and it is in this context that issues of corporate governance, privatisation, capital markets and the like are critical.

To what extent have the economies of Central and Eastern Europe succeeded in reallocating labour towards sectors where it is more productive? Can one assess the efficiency of their labour markets in achieving such reallocation? What explains differences between countries, and what policies can now help in this process? Do high rates of unemployment assist or hinder labour market reallocation? Has the Czech Republic maintained low unemployment by delaying 
economic restructuring, or has it been able to combine full employment and labour market reallocation, and if so, how? In this paper we attempt answers to these questions.

Our main conclusions are first that the labour market of most of the transition economies have been dominated by economy-wide shocks entailing employment decline in almost all sectors rather than by reallocation across sectors. Even so, as the recovery gathers strength reallocation is taking place and in this regard, up to half of the reallocation that may be required in the lead economies (the Czech Republic and Poland) has been achieved within the first five years of the transition. This speed of reallocation compares well with that of less developed market economies such as Greece or Portugal which are adjusting to the European Single Market. Second, the effectiveness of labour market reallocation appears to proceed as rapidly in interventionist countries like the Czech Republic as in free market countries like Poland. The Czech full employment "miracle" has not been bought at the cost of a slower pace of restructuring.

This paper is in four sections. The first attempts a measure of the change in the structure of employment required and the amount so far achieved. The second section identifies measures both of the speed and the efficiency of restructuring, and the effectiveness of new job creation. We argue that new job creation is the most important aspect of restructuring and we show that this measure bears little relationship to aggregate measures of economic performance, such as GDP growth or unemployment. The third offers some thoughts on decision-making within state-owned enterprises, where it is argued that the key to understanding the disparate performance of the economies of Central and Eastern Europe lies in the worker orientated management of the SOEs. The final section looks at policy.

\section{THE REALLOCATION OF LABOUR ACROSS SECTORS}

Despite the pivotal importance of the concept of restructuring in the 
economics of transition, there seem to have been few attempts to measure it. In this paper, we attempt to quantify various measures of restructuring, in the sense of labour reallocation, in order to answer the following types of question:

C How much restructuring is required in each economy?

C How much restructuring has taken place since the reforms?

C How far has the restructuring been successful in reducing the initial structural imbalance (i.e has it been in the right direction, or "convergent")?

C Is the pace of restructuring fast or slow by comparison with the current pace of employment reallocation in market economies?

C Is high unemployment correlated with faster, or better directed, restructuring?

Some models of labour market reallocation have been formulated in terms of ownership. Perhaps most influential have been models developed by Blanchard (1991) and Aghion and Blanchard (1994). Their basic paradigm envisaged three stages in the transition. The initial stage would be characterised by a sharp fall in state sector employment and a sharp rise in unemployment. In the second stage, the growth of private sector firms would draw workers from the pool of unemployment. Unemployment would decline until it reached an equilibrium level, after which, in the third stage, further growth in the private sector would depend on private firms being able to bid away workers from the residual state sector. Some economists went as far as to argue that unemployment could be regarded as an "indicator of the extent to which the restructuring process has got under way" (McAuley, 1991).

We would argue that it is misleading to identify labour market 
reallocation with the development of private ownership. Employment in the private sector can grow simply because enterprises are privatised with no change in any worker's place of employment. Such privatisation may raise efficiency but in general will not remove the need to shed labour from the formerly state-owned manufacturing enterprises. In the context of the labour market, restructuring is more fundamentally an issue of industrial composition. A shift out of agriculture, for example, is needed in most transitional economies whether or not agriculture was initially in state or private ownership. Likewise, one can expect a substantial expansion of employment in activities such as airports or telecommunications, whether or not state owned. Of course, the change in industrial composition will in general be associated with a decline in the state sector (manufacturing) and growth in the private sector (services), but it is the sectoral rather than the ownership shift which necessitates labour reallocation.

This is not to rule out the need for labour mobility between enterprises within the same sector. Differences in management qualities, market access or product mix may allow some enterprises to flourish while others in the same sector decline, and, even within narrowly defined sectors, state firms may be losing out to de novo private activity. Nonetheless, in this paper we will focus on labour mobility across broadly defined (1-digit) industrial sectors, because this is where problems of structural adjustment can be expected to be most severe. In industrialised market economies there is considerable labour mobility within sectors, but there are much larger problems associated with de-industrialisation and the absorption of manufacturing workers into other sectors. Similarly, prior to the reforms, inter-enterprise labour mobility was quite high in Eastern Europe and of the same order of magnitude as in many Western European countries (Jackman and Rutkowski, 1994, Table 7.1). But in the past the bulk of this mobility took the form of people moving between basically similar jobs in similar types of enterprise, and even if job mobility of this form were to remain high, as appears to be the case in Russia and elsewhere in the former FSU (see e.g. Commander et al, 1995), it would make no 
contribution to bringing about the enormous changes in the broad structure of employment that are required.

A second reason for looking at broad industrial sectors concerns the need to distinguish restructuring - which implies change from a less to a more efficient allocation of resources - from simple turbulence, or change in no particular direction. We need to ask whether labour reallocation is moving people to where they are likely to be more productive, and this requires a view of what structure is the ultimate objective. How might one determine a "warranted" or "terminal" employment structure for each country, that is to say the structure that could be expected to develop in the long term given current policies, the "long term" being perhaps a period of time over which the workforce and the built environment are taken as given, but the labour allocation and investment adjust fully to the new regime.

Estimates of the comparative advantage of individual countries in particular sectors (e.g. Hare and Hughes, 1992) typically build in features of the economy, such as the inherited capital stock, which will themselves change during the process of transition. Additionally, they are more feasible for traded goods sectors than for (private or public) services, though the bulk of employment in an efficient allocation is likely to be in the service sector.

Instead, we start from the idea that, to a first approximation, the structure of employment in the Central and Eastern European (CEE) countries should in the long run become more or less the same as in neighbouring market economies. The differences in the inherited employment structure of the CEE economies as compared to a neighbouring market economy can be attributed to the distortions of the planned economy, reflecting the material bias of production, obsolete technology and inappropriate relative factor prices. As these features are removed, the employment structure of CEE countries should come to resemble that of Western European market economies.

One advantage of a direct comparison with a market economy unadjusted for the specific features of the transition economies is that it avoids the need for reliable data on output or the capital stock. Time 
inconsistent and error-infested statistical measures of output or capital stock are a major impediment to any empirical investigation of the economic reform in Eastern Europe, particularly when attempting inter temporal and cross-country comparisons. For historical reasons, labour market data in the former socialist countries tend to be more reliable than other types of quantitative information.

In Table 1, using OECD data which permit direct comparison by broad industrial sector, we document the employment structure of the CEE countries in 1989 with that of Western European comparator economies. For purposes of comparison, we divided Western European countries into a Northern group (Denmark, (West) Germany, Netherlands and UK) and Southern group (France, Greece, Italy and Spain), to allow for the considerable differences in employment in agriculture.

The table indicates the scale of the problem. In comparison with either group of market economies, there is obviously excessive employment in agriculture, mining and manufacturing industry everywhere. Services, particularly trade and finance (which covers business and professional services in addition to banking, insurance etc.) are underdeveloped in all countries. It is noticeable also that "community services" (which include health and education as well as public administration) employ fewer people than in the market economies. On the other hand, employment in construction and transport is much the same.

It is evident from Table 1 that the extent (as against the nature) of structural imbalance differs considerably between countries. In the final rows of the Table, we calculate an "index of restructuring" which measures the proportion of the workforce in each country which would need to change sector to enable the country to attain the same structure of employment as that of a comparable Western European economy, as characterised by either the Northern or the Southern group, in 1989.

As compared with the structure of employment in the Southern European countries, the extent of restructuring required in Romania, at $31.3 \%$ of the workforce was, at the outset, nearly double that 
required in Hungary (16.5\%). While Romania is something of an outlier, the extent of restructuring required was also significantly greater in Bulgaria and (because of its abnormally large agricultural sector) in Poland than in the Czech or Slovak Republics, which are quite similar to Hungary. To attain the same structure as the Northern countries requires a further reallocation of about $3 \%$ in each of the countries.

Turning now to the second question, the amount of restructuring achieved, an obvious measure is simply to replicate Table 1 for a recent year, say 1994, and compare the structural imbalances "now" with those that existed at the outset. The data for such a comparison are shown in Table 2. For various reasons, including German reunification, it is not possible to obtain data on a comparable basis for the Northern group of countries after 1989, so this comparison is undertaken with regard to the Southern group only. This makes very little difference since the direction of labour reallocation is the same on either basis in almost all sectors in every country. The remarkable feature of Table 2 is that the imbalances appear as great now as they were in 1989. While the proportion employed in manufacturing has fallen everywhere, and the proportions employed in trade and finance risen, the proportion employed in agriculture has risen in some of the countries, and, most remarkably, the restructuring index shows very little improvement and has actually slipped back in some countries.

The apparent lack of progress in restructuring despite substantial job losses reflects several phenomena. First, there is a problem of "moving goalposts" — the market economies are themselves in the process of relatively rapid structural change, and the transition economies need quite a rapid pace of employment reallocation simply to avoid falling further behind. (In all cases employment changes in market economies are moving them further away from the employment structure of the transition economies.) If one calculates the gap in employment structure between the transition economies in 1994 and the comparator economies in 1989, all the transition economies show some improvement, most notably the Czech and Slovak Republics. 
Even on this measure, however, progress in Poland and Bulgaria has been very limited and in Romania it has been almost non-existent.

The second reason concerns the peculiar role of the agricultural sector as an "employer of last resort". In some countries, particularly those where employment in agriculture was initially high, the collapse of regular employment has led to a reversion to small-scale farming. There is thus a perverse tendency for those countries which had the greatest surplus of employment in agriculture in 1989 to experience the slowest declines, or even in the case of Romania a sharp increase, in agricultural employment between 1989 and 1992. We return to the special character of agricultural employment in the next section.

Third, and most importantly, a significant part of the change in the employment structure that has been observed has not been attributable to the reallocation of labour across sectors, but simply reflects the uneven incidence of macroeconomic recession. A sector with excess employment at the outset may be shedding labour, but if its rate of employment decline is slower than average, its share of employment will be increasing. In Bulgaria, for example, the shares of employment in mining, electricity, water and transport have all risen, even though the initial shares in these sectors were already too high, presumably because they are less vulnerable to recession.

Some further evidence for this last point is given in Tables A1 and A2 of the Appendix, which show gross changes of employment by sector between 1989 and 1992, and 1992 and 1994 respectively. Between 1989 and 1992 the rate of job destruction ranged from 25.0\% in Bulgaria to $10.2 \%$ in the Czech Republic, while job creation ranged from $6.7 \%$ in Romania to only $0.2 \%$ in Bulgaria. There is an clear inverse relationship between job destruction and job creation measured at the sectoral level, consistent with the dominant role of aggregate shocks relative to sectoral reallocation. It is notable that in most cases even where the share of employment in a particular sector is rising, the absolute level of employment in that sector is falling. Such changes in the structure of employment that took place between 1989 and 1992 were thus achieved almost entirely by differential rates of job loss with 
no need for labour mobility across sectors.

The later period, from 1992 to 1994, shows a reduced rate of job destruction in all countries and a more rapid rate of job creation, and no longer an inverse correlation between the two. By this stage there is evidence of significant job creation, notably in Poland and the Czech Republic, which have achieved relatively rapid rates of growth in the business service sectors, that is trade and finance.

\section{LABOUR REALLOCATION AND AGGREGATE UNEMPLOYMENT}

To assess the extent of effective labour reallocation across sectors it is clearly necessary to look not at employment shares, but at the actual numbers employed in different sectors. With employment falling by $15-20 \%$ in some countries, the immediate issue is how to treat the emergence of unemployment. In large part this depends on whether unemployment is regarded as temporary or permanent. To the extent that the CEE countries are adopting policies and institutions similar to those of Western European countries, they must presumably expect rather similar unemployment rates in the long term. We therefore adopt the principle of the comparator market economies as indicators of likely long term unemployment rates.

It turns out, however, that average unemployment rates in CEE countries are now much the same as in Western Europe. Thus we can regard current CEE unemployment rates as perhaps close to their likely long run equilibrium levels, at least in relation to western Europe as it was at the end of the 1980s. We may then take the allocation of the labour force in the comparator country, including the unemployment rate, as the standard against which labour reallocation can be measured. Thus for each CEE country we calculate, given the size of its 1994 labour force, how many people would be employed in each sector and how many would be unemployed if it were to have the same structure of employment and the same unemployment rate as the comparator Western European economy (as of 1989). 
For this purpose we return to the Northern and Southern groups of comparator market economies set out in Table 1. The differences between these groups can be attributed in part to permanent features of the economic landscape such as climate or population density. It is conspicuous that in comparison with Northern Europe the CEE imbalance is concentrated almost exclusively in agriculture, where the CEE average of around $24 \%$ contrasts with only $4 \%$ in the Northern European countries. It would seem appropriate to allow for persistent differences along these lines in CEE countries also, and in the comparisons that follow we use the Northern countries as the comparator group for the Czech and Slovak republics and for Hungary and the Southern countries as a comparator group for the others (Poland, Bulgaria and Romania).

This provides a basis for comparing the actual changes in employment, measured in terms of overall sectoral declines or increases, with those which would be required for the structure of employment to adjust to that of the comparator market economy.

The data and calculations for each of the CEE countries are presented in Tables A3 - A8 in the Appendix. The first three columns set out the data - actual employment and unemployment in 1989 and 1994 and the employment structure based on the comparator market economy. The next two columns contrast the changes in employment which have occurred with those which would have been required to replicate the employment structure of the comparator economy.

On this basis we may construct a measure which takes account not only of the totality of sectoral employment changes, but also of the direction of such changes. The "warranted" or "convergent" change in employment (column 5) can then be compared with the actual change in employment between 1989 and 1994 (column 4). Where the two figures have the same sign, either positive or negative, we can measure the amount of restructuring achieved by the smaller of the two. Where the actual and convergent changes have opposite signs, no restructuring is deemed to have taken place. Hence for each economy we can compute the total extent of labour reallocation in the convergent 
direction, that is restructuring achieved (column 6), as compared with labour reallocation going in the "wrong" direction or overshooting the adjustment required (column 7).

These calculations permit a number of measures of the success of labour reallocation. First we can ask what proportion of the labour reallocation "required" has taken place in the first five years, which we may measure as the absolute sum of the numbers in column 6 divided by the absolute sum of those in column 5 . This gives a measure of the speed of restructuring. The results of these calculations are presented in Table 3, which suggests that on average about $40 \%$ of the employment changes to achieve convergence had already taken place by 1994 , with the highest figure being for Hungary (60\%), and the lowest for Romania.

It is also possible to derive a measure of the "efficiency" of labour market reallocation, that is to say the proportion of the total employment change that has been convergent towards the warranted structure. This is measured by the absolute sum of the numbers in column 6 as a proportion of the absolute sum of those in column 4. If labour reallocation is costly, it is important to avoid unnecessary structural change, and one may wish to balance these costs against the costs of slower adjustment. In all countries over $60 \%$ of employment changes have been convergent, with the Czech Republic achieving the highest efficiency, over $90 \%$, on this criterion.

By way of comparison, we have made similar calculations for two relatively non-industrialised market economies in southern Europe, Greece and Portugal, which have recently become members of the EU and are now to some extent subject to the rigours of the European Single Market. In terms of the speed of restructuring, Portugal has achieved a more rapid change than any of the CEE countries while Greece is at the lower end of the range. Similarly, Portugal does well on the efficiency index while Greece is worse than any of the CEE countries. The differences between these two countries, and the differences amongst the CEE countries, are evidently larger than the differences between the two groups. 
The measure of restructuring we have adopted comprises two qualitatively rather different activities: job losses in sectors with excess employment and job creation in sectors with deficient employment. But clearly, destroying redundant jobs, for all the social costs involved, remains an economically easier task than creating new jobs. The amount of new job creation required for convergence varies from over $24 \%$ of the labour force in Romania to about $16.5 \%$ in Poland and Slovakia to $12.5 \%$ in Bulgaria, Hungary and the Czech Republic, the low figure for Bulgaria being largely because of the sharp drop in its labour force which permits a larger part of the restructuring process to be achieved through differential job loss.

In the final column of Table 3, we have calculated a new job creation index, which is the number of new jobs created in the sectors with deficient employment as a proportion of the total new job creation required for convergence. On this measure, the Czech Republic is the most successful of the transition economies, with $28 \%$ of new job creation already achieved, followed by Poland, Slovakia and Hungary. Bulgaria and Romania have made virtually no progress at all on this definition. It is also noteworthy that on the basis of the new job creation index, both Greece, and to an even greater extent Portugal, are far ahead of any of the CEE countries.

The final question concerns the relationship between restructuring and unemployment. Does unemployment assist the process of restructuring? Clearly, the answer depends on the measure chosen. We would argue that the objective of restructuring from a labour market perspective is to create jobs in the growth potential deficient employment sectors. It is a hypothesis that this process may be assisted by a rapid rate of job destruction and transitional unemployment, but job destruction and unemployment should not be seen as policy objectives, but only as a means to an end, the objective being new job creation.

On this measure, as we have already noted, the Czech Republic is the most successful of the CEE economies and this experience appears to suggest that employment growth in private services may be 
assisted by a more gradual pace of job loss in the state sector. The next most successful economy on this criteria, however, is Poland which, by contrast, is an economy of high unemployment (in particular in relation to its output growth). The relationship between unemployment and the pace of job creation in the growing sectors is shown in Figure 1, which suggests that there is no clearcut relationship, with the Czech Republic a clear outlier.

The explanation of the absence of any correlation between restructuring and unemployment appears a relatively simple one, namely that unemployment is not the route by which workers move between sectors. The Hungarian Household Panel Survey (Kollo, 1993) found that most workers in private firms were recruited directly from state firms, whilst a majority of the unemployed who found jobs returned to state sector employers, and in fact more people entered unemployment from the private sector than unemployed people found work in the private sector. Similar results were found in the former Czechoslovakia (Vercenik, 1992), in Poland (Boeri, 1993) and a survey of recruitment by private sector firms in Bulgaria (Beleva et al, 1995) found that virtually none hired unemployed people.

The evidence that growing firms recruit from those in work rather than from the unemployed does not mean that there is no link between unemployment and restructuring. If growing firms are recruiting from the state sector the wage they will have to pay will obviously depend on the wages paid in state firms, which in turn may be sensitive to the unemployment rate. However, in economies where flows out of unemployment are low (Boeri, 1994), wage setting in firms would in principle be much more sensitive to the income available to the unemployed, in particular the level and duration of unemployment benefit, than to the impact of changes in the unemployment rate on their prospects of finding another job.

The finding that unemployment is unnecessary for successful restructuring, as measured in terms of labour mobility, raises two further questions. First, if the Czech full employment achievement is not accounted for by slow restructuring, how is it to be explained, and 
indeed what are the main causes of the very different evolution of unemployment (both absolutely and relative to output) across countries? Second, what policy actions can countries now take to enable them to reduce unemployment without prejudicing the progress of economic transition?

\section{EMPLOYMENT DECISIONS OF STATE FIRMS}

Given the dominant role of the collapse of output in the immediate aftermath of the recession, it would be natural to presume that the unemployment rate of an economy would be determined primarily by the magnitude of the aggregate decline in output. But, as shown in Table 4, there are in fact large and significant differences between output and employment changes and between employment and unemployment changes in the first years of transition. In some countries the fall in output has been associated with much larger falls in employment than in others. Given the initial concentration of output and employment in state firms, it is in their behaviour that some understanding of the differences in behaviour may be sought.

How might one model the wage and employment decisions of worker or manager controlled enterprises subject to the disruptive consequences of economic transition? We do not attempt a systematic review of this issue, but instead focus on the critical question of when an enterprise facing an adverse demand shock resorts to laying off workers. We follow the standard presumption that, in the interval between the collapse of central planning and the institution of private ownership, the prime objective of the state-owned enterprise (SOE) has been the welfare of its workforce. In attaining this objective, it is important to recognise that the SOE can separate output and employment decisions, and that the production function is not necessarily a binding constraint. Price and output decisions are made to maximise revenue in the product market subject to the constraint of demand. Wage and employment decisions are then made in the interests 
of workers' welfare, subject to the financial constraint. (For a model developing this idea, see Jackman et al, 1992.)

Some evidence in support of this interpretation is given in Table 5. Over the period 1990—93, the correlation between changes in output and changes in employment across narrow (2-digit) sectors in manufacturing in Poland is only 0.30. Notably, the correlation between product price and output is negative, though again weak, while the correlation between product price and the number of employees is positive. Most strikingly, there is a much stronger correlation between revenue and employment. All this appears consistent with the idea that employment is determined by the number of workers firms can afford to pay, rather than by their production requirements.

Enterprises facing an adverse shock can then choose to reduce production but maintain employment. In such an enterprise, worker effort must necessarily fall in line with the fall in productivity, and if there is no change in the relative product price the real consumption wage must also fall in the same proportion. In Romania, for example, survey evidence suggests that average hours worked have fallen from around 2,100 a year in 1989 to only 1,500 a year in 1992.

To explain differences in behaviour across countries, it is helpful to envisage three stages of enterprise response to adverse shocks. First, it may be able to protect both wages and employment in the face of falling revenues by reducing other costs, by not replacing workers who leave and taking advantage of any remaining softness in the budget constraint. Second, it can maintain employment with lower work effort and lower real wages. It will want to cut wages for so long as the wage income it can pay exceeds the income its workers can get outside the firm, i.e. primarily unemployment benefit. Only when other sources of savings have been exhausted, and wages have been cut to the outside opportunity, will it be forced into laying off workers.

There is evidence that labour shedding in the first phase took the form mainly of voluntary separations. This process takes various forms: retirements and early retirements; in some countries emigration or others wanting to leave the labour force; but above all workers leaving 
to take (what they hope will be) better jobs in the growing sectors of the economy dominated by de novo private firms. A number of studies have documented a rate of separation from state sector firms in the first few years of the transition no higher than their normal levels prior to the reforms (see, for example Beleva et al, 1995, for Bulgaria, or Earle and Oprescu, 1995, for Romania).

One of the most important differences between countries has been the extent to which various forms of deficit finance have been allowed to continue. Poland and Hungary have perhaps been least tolerant, as was Bulgaria in the initial stages of the transition. The ending of the soft budget constraint in these countries has forced a greater degree of adjustment of wages and employment. In Romania, by contrast, much of state owned industry, particularly heavy industry and mining, continued to receive financial support. In the Czech Republic, selective subsidy and other forms of directed support have permitted many state enterprises to maintain employment despite being subject to major demand shocks.

Where SOEs are obliged to cut into their wage bills, and therefore to reduce either wages or employment or both, the key issue is the expected income of workers laid off from the enterprise. It has been clear from an early stage that the labour market prospects of unemployed workers were very weak. The alternative sources of income for most workers consist largely of unemployment benefits, casual informal work or the support of their families. Differences in unemployment benefit regimes constitute a further element in understanding the different experiences of the different countries.

Unemployment benefit regimes in CEE countries appear at first sight rather generous, with replacement rates as high as $75 \%$ in Hungary and around $60 \%$ elsewhere. In fact, these ratios give a misleading picture: benefits are often capped and their real value in some countries is quickly eroded by inflation. Even more importantly, the duration of benefit entitlement is limited to only six months in the Czech Republic and typically about a year elsewhere (Boeri, 1994; Scarpetta and Reutersward, 1994). In some of the countries, particularly Poland, the 
benefit regime was initially more lenient in terms of eligibility and duration, and this allowed some unemployment and particularly longterm unemployment to build up. One consequence has been that it has become difficult for benefit officers to monitor the activities of the unemployed so that it is, for example, common for unemployed people to work in the informal sector.

It is perhaps the combination of hard budget constraints at the level of the enterprise and a relatively generous stance on benefits in Hungary and Poland which accounts for the willingness of enterprises in these countries to lay off workers rather than cut wages. From the perspective of a worker managed firm, unemployment benefits reintroduce, at the level of the household, the soft budget constraint in the sense of providing public financial support for the enterprise conditional on making its workers unemployed. In the Czech Republic, and to some extent also in Romania, a different policy stance, more supportive of firms but tougher on unemployed people, has encouraged enterprises to retain their workers.

\section{POLICY}

From the outset, labour market policy in the transition economies has been based on the recognition of the need for substantial reallocation of labour across sectors. It was thought that employment restructuring might lead to high, albeit temporary, unemployment because the speed of job loss in declining sectors could be expected to be very much more rapid than the rate of new job creation in the growing sectors. Further, the sectoral reallocation of labour could be impeded by various obstacles to labour mobility, such as poorly developed employment exchanges or the absence of an effective housing market. In this framework, the key elements of labour market policy were seen to be (a) subjecting firms to hard budget constraints to force rapid restructuring, (b) encouraging labour mobility and wage flexibility and (c) provision of benefits, or some form of "social safety net", for those temporarily 
stranded between the collapse of jobs in the state sector and the growth of the private sector.

We have argued that such a perspective may have been mistaken. It is not in our view correct to think that unemployment in the transition was an inevitable component of reallocation. The Czech Republic, which has achieved the most rapid rate of new job creation in the growth sectors (trade and finance), has the lowest unemployment rate in Europe. Overall, our empirical work suggests that there is no correlation between the rate of new job creation and the rate of decline of employment in the sectors with excessive employment. The belief that unemployment is needed in the particular circumstances of the transition because it would facilitate the movement of workers into growth sectors, seems to us mistaken - private firms appear to recruit almost exclusively from those with jobs in the state sector or new entrants to the labour force rather than from the unemployed.

Thus we would question the rationale of policies directed at speeding up the shake-out of labour from the excess employment sectors. By creating open unemployment, such policies burden the public finances and additionally may create problems of deterioration of morale and work habits amongst those made unemployed. It remains an option for state firms to maintain employment, and the extent to which they exercise that option can be influenced by policy. What principles ought then to guide policy?

Clearly the main objective must be to encourage the growth of the new private sector. While high rates of unemployment do not of themselves contribute to this objective, policy initiatives to reduce unemployment could well be harmful to private sector employment. For example, a policy of indefinite and indiscriminate support for maintaining employment in declining firms financed by taxes on private firms would have a severe adverse effect on the private sector. Rather what is needed are policies to equate the private and social costs of layoffs, as against the present situation where the state subsidises layoffs but not employment.

One extreme would be simply to abolish unemployment benefits, 
as is approximately the case in Russia. The main effect of this policy has been to bring about very sharp cuts in real wages in conjunction with the maintenance of high levels of employment in state (or formerly state) firms. Registered unemployment in Russia remains very low, and, even on Labour Force Survey measures, the 1995 rate is below $8 \%$. Given a decline of output in Russia of close on $50 \%$ this is a remarkably low number. But the consequence has been an enormous increase in hardship, poverty and inequality in Russia to an extent which would be unacceptable in most of Eastern Europe.

An alternative approach, for which the Czech experience offers some support, is one based on restricting the availability of unemployment benefits on some "workfare" principle. In such programmes, the state provides income support in conjunction with requiring unemployed people to undertake some publicly useful work. Workfare not only diminishes the possible attractions of unemployment particularly to those with informal sector opportunities or to the idle, but also tends to encourage the unemployed to search more actively for regular work. Hence it leads to lower wages being set in firms than if unemployment benefits were set at the same level but with no work obligation.

The balance of policies in the Czech Republic has involved a relatively short duration of "unconditional" unemployment benefits, followed after six months by a work guarantee programme on workfare lines. By accompanying this policy with selective support of state firms, the Czech Republic has achieved a better balance in terms of both encouraging the growth of jobs in the private sector and restraining the decline in employment in the state sector. (For more detailed evaluation of the Czech experience, see Boeri and Burda, forthcoming; Ham et al, 1995.) This policy mix may offer a more attractive model for other CEE countries.

Looking further into the nature of unemployment in the transition economies, it is notable that both the eligibility and the duration of unemployment benefits are limited, yet many people seem able to support themselves for long periods of unemployment. For example, in 
Bulgaria only $24 \%$ of those reported as unemployed in the June 1994 Labour Force Survey were receiving unemployment benefits, leaving 550,000 people (over $15 \%$ of the labour force) reporting themselves as unemployed without benefits and in most cases without other forms of state income support.

Clearly, it is possible that many of those registered as, or reporting themselves, unemployed may also have some form of casual or informal work, given in particular that many of the East European countries have sizeable agricultural sectors, and some also have thriving informal sectors. There has been widespread concern, not least in the countries themselves, about abuse of the benefit system, though there is little hard evidence. However, in Poland one survey found that $46 \%$ of unemployed people had some form of work, albeit often only casual or part-time (World Bank, 1995), while a second survey found that around $35 \%$ of employers were hiring informally people registered as unemployed (Mroczkowski, 1996). Unemployment is thus becoming linked to the growth of the (non-tax paying) shadow economy.

The transition economies typically have both high benefits, albeit with restricted coverage, and high employment taxes, which together create strong incentives for evasion. This suggests a possible new role for active labour market policies: by linking payment of benefit to some temporary job, the employer is of necessity brought into the formal sector. Traditionally, evaluations of active labour market policies in CEE countries, as in OECD economies, have tended to be unfavourable, reflecting the fact that active policies are designed to overcome impediments to mobility when the problem in most $\mathrm{CEE}$ countries has been an overall shortage of jobs (OECD, forthcoming; Puhani and Steiner, 1996). But these evaluations have been primarily concerned with the future job prospects of participants rather than with the growth of the shadow economy. A gradual introduction of workfare style active labour policies, say in terms of providing a temporary job or training after six months unemployment for those under 25, as a condition for continued receipt of benefit could have an important role in retaining people in the official labour market, and discouraging the 
growth of the shadow economy.

The main conclusion of this paper is that unemployment in the transition economies has been neither necessary nor efficient from the perspective of labour market restructuring. It has rather been the consequence of misguided policies which have subsidised socially inefficient job destruction. The outcome has been high and persistent unemployment. Labour market policy is thus still required to restrain the growth of wages, either through reducing unemployment benefits or by combining benefits with workfare based active labour market policies. 


\section{DATA APPENDIX}

\section{SOURCES}

i) OECD employment by sector. The data is from OECD-Labour Force Statistics (1993). The southern group of OECD countries consists of France, Greece, Italy and Spain, the northern group consists of Denmark, Germany (West), the Netherlands and the United Kingdom. The figures for each group are weighted averages.

ii) Eastern European countries. The main data source is Employment Observatory - Central and Eastern Europe No. 8, 1996, (European Commission (DG V), Brussels), except for Romania, where we use the Statistical Yearbook (1995) published by the Romanian Commission for Statistics. These data derive primarily from administrative sources, typically enterprise based Censuses, supplemented by various ad hoc estimates of the private sector and, since 1992 or 1993, by labour force surveys. Data is end year. Further details for individual countries are as follows:

\section{Bulgaria}

The primary sources of data for the whole period are the National Statistical Institute and the Ministry of Labour and Social Welfare. The labour force and employment figures are administrative data derived from establishment Censuses together with official estimates of employment in the private sector.

\section{Czech Republic and Slovakia}

Up to and including 1992, the data are based on establishment surveys. The figures are total number of jobs (i.e. multiple job holders are counted more than once) and exclude apprentices and women on maternity leave. After 1993, the data come from the Labour Force 
Survey which, however, adopts a broadly similar industrial classification.

\section{Hungary}

Up to 1991, the data are derived from the labour accounts of the Central Statistical Office. From 1992, they come from the Labour Force Survey, with broadly similar industrial classification. The unemployment rate is the official one and includes women on maternity leave.

\section{Poland}

Data are from administrative records throughout plus sample surveys of small enterprises conducted by the Central Statistical Office and also, in the case of agriculture, from Census figures and the Labour Force Survey.

\section{Romania}

Data come from administrative sources of the National Commission for Statistics. Figures include official estimates of employment in the private sector. 


\section{TABLE 1}

Structure of employment (\%) in 1989

\begin{tabular}{|l|c|c|c|c|c|c|c|c|}
\hline Sector & Bulgaria & Czech & Hungary & Poland & Romania & Slovakia & $\begin{array}{c}\text { South } \\
\text { OECD }\end{array}$ & $\begin{array}{c}\text { North } \\
\text { OECD }\end{array}$ \\
\hline Agriculture & 19.0 & 11.7 & 16.6 & 26.8 & 27.9 & 13.8 & 10.7 & 4.1 \\
Mining & 2.6 & 3.6 & 2.0 & 3.4 & 2.3 & 1.0 & 0.4 & 1.0 \\
Manufacturing & 34.9 & 34.0 & 28.6 & 24.5 & 33.0 & 32.1 & 22.0 & 26.3 \\
Electricity, gas, & 0.8 & 1.4 & 2.6 & 1.1 & 1.2 & 1.6 & 0.9 & 1.1 \\
water & & & & & & & & \\
Construction & 7.8 & 7.3 & 7.0 & 7.8 & 7.0 & 11.6 & 8.1 & 6.4 \\
Trade & 9.2 & 11.5 & 11.3 & 8.9 & 5.9 & 11.1 & 19.3 & 17.4 \\
Transportation & 6.8 & 6.5 & 7.7 & 7.2 & 6.9 & 6.4 & 6.0 & 6.0 \\
Finance & 0.6 & 0.5 & 0.8 & 1.0 & 0.3 & 0.4 & 6.1 & 8.6 \\
Community & 18.4 & 23.5 & 23.4 & 19.3 & 15.3 & 22.0 & 26.5 & 28.7 \\
services & & & & & & & & \\
RI-South & 24.2 & 17.2 & 16.5 & 23.0 & 31.3 & 18.4 & - & 10.0 \\
RI-North & 27.3 & 19.6 & 19.6 & 27.7 & 33.4 & 21.6 & 10.0 & - \\
\hline
\end{tabular}

Source: See data appendix.

Notes: 1) South OECD countries are France, Greece, Italy and Spain.

North OECD countries are Denmark, West Germany, Great Britain and the Netherlands.

2) RI is the coefficient of restructuring, defined as the overall excess employment in sectors where the proportion employed in the Eastern European country exceeds employment in the comparator countries (South, respectively North, OECD). 
TABLE 2

Structure of employment (\%) in 1994

\begin{tabular}{|l|c|c|c|c|c|c|c|}
\hline Sector & Bulgaria & Czech & Hungary & Poland & Romania & Slovakia & $\begin{array}{l}\text { South } \\
\text { OECD }\end{array}$ \\
\hline Agriculture & 23.2 & 7.0 & 8.7 & 26.7 & 35.6 & 10.2 & 8.3 \\
Mining & 3.1 & 2.0 & 1.0 & 2.7 & 2.6 & 1.6 & 0.4 \\
Manufacturing & 29.4 & 29.7 & 23.7 & 20.3 & 24.5 & 26.8 & 20.5 \\
Electricity, gas, & 1.1 & 2.0 & 2.9 & 1.9 & 1.7 & 2.3 & 0.8 \\
water & & & & & & & \\
Construction & 5.9 & 9.3 & 5.4 & 5.7 & 5.6 & 8.9 & 8.3 \\
Trade & 10.9 & 15.0 & 15.4 & 14.6 & 6.7 & 12.3 & 19.5 \\
Transportation & 7.2 & 7.6 & 8.4 & 5.7 & 5.6 & 7.8 & 6.0 \\
Finance & 1.4 & 1.6 & 1.9 & 1.6 & 0.6 & 1.2 & 7.2 \\
Community & 17.7 & 25.9 & 32.5 & 20.8 & 17.2 & 29.0 & 28.5 \\
services & & & & & & & \\
RI-South & 28.2 & 14.6 & 12.7 & 21.8 & 34.4 & 13.6 & - \\
\hline
\end{tabular}

Source: See data appendix.

Note: As Table 1. 


\section{TABLE 3}

Restructuring indices, 1989—1994

\begin{tabular}{|l|cc|cc|c|}
\hline & \multicolumn{2}{|c|}{ Speed } & \multicolumn{2}{c|}{ Efficiency } & New Job Creation (\%) \\
\hline Bulgaria & 40.5 & $(48.2)$ & 70.0 & $(66.8)$ & 3.9 \\
Czech R. & 44.2 & $(39.6)$ & 90.7 & $(87.2)$ & 28.0 \\
Hungary & 60.3 & $(54.5)$ & 84.1 & $(76.0)$ & 12.8 \\
Poland & 35.3 & $(44.4)$ & 70.6 & $(64.8)$ & 23.3 \\
Romania & 21.1 & $(30.5)$ & 64.8 & $(84.2)$ & 3.4 \\
Slovakia & 48.7 & $(48.8)$ & 92.5 & $(90.3)$ & 19.1 \\
Greece* & 26.3 & & 57.0 & & 41.9 \\
Portugal* & 70.1 & & 85.9 & & 89.9 \\
\hline
\end{tabular}

*1989-1993

Source: Authors' computations.

Note: Indices in brackets exclude agriculture. 


\section{TABLE 4}

Output, Employment and Unemployment in Central and Eastern Europe

\begin{tabular}{|c|c|c|c|c|c|c|}
\hline & \multicolumn{2}{|c|}{ 1989-1992 } & 1992 & \multicolumn{2}{|c|}{ 1989-1995 } & 1994 \\
\hline & $\sigma_{\text {fDP }}$ & $\sqrt{\mathbb{E}}$ & $\mathrm{U}$ & $\overline{C F}_{\text {GDP }}$ & $\sqrt{\mathbb{E}}$ & $\mathrm{U}$ \\
\hline & $\%$ & $\%$ & $\%$ & $\%$ & $\%$ & $\%$ \\
\hline Bulgaria & -26 & -25 & 16 & -25 & -25 & 13 \\
\hline Czech R. & -19 & -9 & 3 & -15 & -9 & 3 \\
\hline Hungary & -18 & -21 & 12 & -14 & -26 & 10 \\
\hline Poland & -17 & -13 & 14 & -3 & -16 & 16 \\
\hline Romania & -26 & -4 & 8 & -19 & -11 & 11 \\
\hline Slovakia & -21 & -15 & 11 & -16 & -13 & 15 \\
\hline
\end{tabular}

Source: GDP, EBRD Transition Report, pp. 185-207. 


\section{TABLE 5 \\ Poland}

\begin{tabular}{|c|c|c|c|c|c|}
\hline \multicolumn{6}{|c|}{ CORRELATION BETWEEN CHANGES IN: } \\
\hline \multirow[t]{4}{*}{ 89-90 } & & Employees & Product price & Industrial prod. & \\
\hline & Employees & 1.00 & & & \\
\hline & Product price & 0.54 & 1.00 & & \\
\hline & Industrial prod. & 0.50 & 0.49 & 1.00 & \\
\hline \multirow[t]{5}{*}{$90-91$} & & Employees & Product price & Industrial prod. & Revenue \\
\hline & Employees & 1.00 & & & \\
\hline & Product price & 0.31 & 1.00 & & \\
\hline & Industrial prod. & 0.49 & 0.42 & 1.00 & \\
\hline & Revenue & 0.47 & 0.92 & 0.69 & 1.00 \\
\hline \multirow[t]{5}{*}{$91-92$} & & Employees & Product price & Industrial prod. & Revenue \\
\hline & Employees & 1.00 & & & \\
\hline & Product price & 0.67 & 1.00 & & \\
\hline & Industrial prod. & -0.09 & -0.11 & 1.00 & \\
\hline & Revenue & 0.20 & 0.00 & 0.70 & 1.00 \\
\hline \multirow[t]{5}{*}{$92-93$} & & Employees & Product price & Industrial prod. & Revenue \\
\hline & Employees & 1.00 & & & \\
\hline & Product price & -0.04 & 1.00 & & \\
\hline & Industrial prod. & 0.27 & -0.66 & 1.00 & \\
\hline & Revenue & 0.09 & 0.91 & -0.29 & 1.00 \\
\hline \multirow[t]{5}{*}{$90-93$} & & Employees & Product price & Industrial prod. & Revenue \\
\hline & Employees & 1.00 & & & \\
\hline & Product price & 0.40 & 1.00 & & \\
\hline & Industrial prod. & 0.30 & -0.37 & 1.00 & \\
\hline & Revenue & 0.71 & 0.78 & 0.20 & 1.00 \\
\hline
\end{tabular}

Source: Central Statistical Office 
TABLE A1

Change in employment (mil.) 1989-1992

\begin{tabular}{|c|c|c|c|c|c|c|c|}
\hline Sector & Bulgaria & Czech & Hungary & Poland & Romania & Slovakia & South OECD \\
\hline Agriculture & -0.12 & -0.20 & -0.36 & -0.72 & 0.39 & -0.08 & -1.21 \\
\hline Mining & -0.01 & -0.07 & -0.05 & -0.12 & 0.01 & 0.00 & 0.00 \\
\hline Manufacturing & -0.57 & -0.26 & -0.35 & -0.89 & -0.75 & -0.18 & -0.51 \\
\hline $\begin{array}{l}\text { Electricity, gas, } \\
\text { water }\end{array}$ & 0.00 & 0.01 & -0.02 & -0.04 & 0.03 & 0.00 & -0.07 \\
\hline Construction & -0.2 & 0.02 & -0.13 & -0.26 & -0.19 & -0.07 & 0.31 \\
\hline Trade & -0.07 & 0.00 & 0.04 & 0.17 & 0.28 & -0.04 & 0.41 \\
\hline Transport & -0.05 & 0.02 & -0.03 & -0.25 & -0.11 & 0.00 & 0.12 \\
\hline Finance & 0.01 & 0.03 & 0.03 & 0.03 & 0.02 & 0.01 & 0.77 \\
\hline $\begin{array}{l}\text { Community } \\
\text { services }\end{array}$ & -0.07 & -0.01 & 0.04 & -0.24 & -0.18 & 0.03 & 1.44 \\
\hline Total Change & -1.08 & -0.48 & -0.83 & -2.33 & -0.50 & -0.34 & 1.74 \\
\hline Job Creation & 0.01 & 0.08 & 0.11 & 0.20 & 0.73 & 0.04 & 3.05 \\
\hline$-\%-$ & 0.2 & 1.5 & 2.2 & 1.2 & 6.7 & 1.6 & 5.3 \\
\hline Job Destruction & -1.09 & -0.55 & -0.94 & -2.53 & -1.23 & -0.38 & -1.79 \\
\hline$-\%-$ & 25.0 & 10.2 & 19.1 & 14.9 & 11.2 & 15.2 & 3.1 \\
\hline $\mathrm{RI} \%$ & 12.6 & 5.9 & 10.7 & 8.1 & 9.0 & 8.4 & 4.2 \\
\hline
\end{tabular}

$\mathrm{RI}=$ coefficient of restructuring

Source: Author's computations based on data sources described in data appendix. 
TABLE A2

Change in employment (mil.) 1992-1994

\begin{tabular}{|c|c|c|c|c|c|c|}
\hline Sector & Bulgaria & Czech & Hungary & Poland & Romania & Slovakia \\
\hline Agriculture & 0.06 & -0.09 & -0.13 & 0.08 & 0.12 & -0.05 \\
\hline Mining & 0.00 & -0.03 & -0.01 & -0.07 & -0.02 & 0.01 \\
\hline Manufacturing & 0.03 & -0.14 & -0.17 & -0.31 & -0.41 & -0.06 \\
\hline $\begin{array}{l}\text { Electricity, gas, } \\
\text { water }\end{array}$ & 0.00 & 0.00 & 0.00 & 0.13 & 0.01 & 0.01 \\
\hline Construction & 0.00 & 0.04 & -0.02 & -0.23 & -0.02 & -0.03 \\
\hline Trade & 0.02 & 0.11 & -0.02 & 0.46 & -0.26 & 0.02 \\
\hline Transport & 0.00 & 0.00 & -0.03 & -0.13 & -0.09 & 0.00 \\
\hline Finance & 0.01 & 0.03 & 0.00 & 0.04 & 0.00 & 0.01 \\
\hline $\begin{array}{l}\text { Community } \\
\text { services }\end{array}$ & -0.15 & 0.03 & 0.03 & 0.18 & 0.22 & 0.03 \\
\hline Total Change & -0.04 & -0.05 & -0.34 & 0.15 & -0.45 & -0.06 \\
\hline Job Creation & 0.12 & 0.22 & 0.04 & 0.89 & 0.35 & 0.08 \\
\hline$-\%-$ & 3.7 & 4.5 & 0.98 & 6.1 & 3.3 & 3.7 \\
\hline Job Destruction & -0.15 & -0.26 & -0.38 & -0.74 & -0.80 & -0.14 \\
\hline$-\%-$ & 4.6 & 5.3 & 9.3 & 5.0 & 7.6 & 6.5 \\
\hline $\mathrm{RI} \%$ & 4.2 & 4.9 & 5.2 & 5.6 & 5.5 & 5.1 \\
\hline
\end{tabular}

$\mathrm{RI}=$ coefficient of restructuring

Source: See data appendix 


\section{TABLE A3 \\ Bulgaria}

\begin{tabular}{|c|c|c|c|c|c|c|c|}
\hline & \multicolumn{3}{|c|}{ Labour Force } & \multirow{2}{*}{$\begin{array}{c}\text { Change in } \\
\text { employment } \\
1989-94 \\
(2)-(1)\end{array}$} & \multirow{2}{*}{$\begin{array}{c}\text { Employment } \\
\text { differential } \\
1989 \\
(3)-(1)\end{array}$} & \multirow[t]{2}{*}{ Convergent } & \multirow{2}{*}{$\begin{array}{c}\text { Non- } \\
\text { Convergent }\end{array}$} \\
\hline & $\begin{array}{c}\text { Actual } \\
1989\end{array}$ & $\begin{array}{r}\text { Actual } \\
1994 \\
\end{array}$ & $\begin{array}{c}\text { Comparator } \\
\text { country }\end{array}$ & & & & \\
\hline & $(1)$ & $(2)$ & (3) & (4) & (5) & (6) & (7) \\
\hline Agriculture & 814 & 732 & 317 & -82 & -497 & -82 & - \\
\hline Mining & 114 & 98 & 15 & -16 & -99 & -16 & - \\
\hline Manufacturing & 1496 & 927 & 698 & -569 & -798 & -569 & - \\
\hline Electricity & 36 & 35 & 26 & -1 & -10 & -1 & - \\
\hline Construction & 333 & 186 & 258 & -147 & -75 & -75 & -72 \\
\hline Trade & 395 & 344 & 613 & -51 & 218 & - & -51 \\
\hline Transportation & 290 & 227 & 192 & -63 & -98 & -63 & - \\
\hline Finance & 26 & 44 & 203 & 18 & 177 & 18 & - \\
\hline $\begin{array}{l}\text { Community } \\
\text { services }\end{array}$ & 788 & 558 & 853 & -230 & 65 & - & -230 \\
\hline Unemployment & - & 537 & 517 & 537 & - & - & - \\
\hline Total & 4292 & 3688 & 3688 & -604 & | 2037 | & | $824 \mid$ & |353| \\
\hline
\end{tabular}




\section{TABLE A4 \\ Czech Republic}

\begin{tabular}{|c|c|c|c|c|c|c|c|}
\hline & \multicolumn{3}{|c|}{ Labour Force } & \multirow{2}{*}{$\begin{array}{c}\text { Change in } \\
\text { employment } \\
\text { 1989-94 } \\
(2)-(1)\end{array}$} & \multirow{2}{*}{$\begin{array}{c}\text { Employment } \\
\text { differential } \\
1989 \\
(3)-(1)\end{array}$} & \multirow[t]{2}{*}{ Convergent } & \multirow{2}{*}{$\begin{array}{c}\text { Non- } \\
\text { Convergent }\end{array}$} \\
\hline & $\begin{array}{c}\text { Actual } \\
1989 \\
\end{array}$ & $\begin{array}{r}\text { Actual } \\
1994 \\
\end{array}$ & $\begin{array}{c}\text { Comparator } \\
\text { country }\end{array}$ & & & & \\
\hline & $(1)$ & $(2)$ & (3) & (4) & $(5)$ & (6) & (7) \\
\hline Agriculture & 631 & 340 & 151 & -291 & -480 & -291 & - \\
\hline Mining & 197 & 99 & 30 & -98 & -167 & -98 & - \\
\hline Manufacturing & 1839 & 1444 & 1165 & -395 & -674 & -395 & - \\
\hline Electricity & 78 & 96 & 45 & 18 & -33 & - & 18 \\
\hline Construction & 392 & 454 & 292 & 62 & -100 & - & 62 \\
\hline Trade & 620 & 729 & 802 & 109 & +182 & 109 & - \\
\hline Transportation & 351 & 370 & 267 & 19 & -84 & - & 19 \\
\hline Finance & 25 & 78 & 418 & 53 & 393 & 53 & - \\
\hline $\begin{array}{l}\text { Community } \\
\text { services }\end{array}$ & 1243 & 1261 & 1310 & 18 & 67 & 18 & - \\
\hline Unemployment & - & 172 & 549 & 172 & - & - & - \\
\hline Total & 5376 & 5043 & 5043 & -333 & | $2180 \mid$ & $|964|$ & 99 \\
\hline
\end{tabular}




\section{TABLE A5 \\ Hungary}

\begin{tabular}{|c|c|c|c|c|c|c|c|}
\hline & \multicolumn{3}{|c|}{ Labour Force } & \multirow{2}{*}{$\begin{array}{c}\text { Change in } \\
\text { employment } \\
\text { 1989-94 } \\
(2)-(1)\end{array}$} & \multirow{2}{*}{\begin{tabular}{|c|} 
Employment \\
differential \\
1989 \\
$(3)-(1)$ \\
\end{tabular}} & \multirow[t]{2}{*}{ Convergent } & \multirow{2}{*}{$\begin{array}{c}\text { Non- } \\
\text { Convergen }\end{array}$} \\
\hline & $\begin{array}{c}\text { Actual } \\
1989\end{array}$ & $\begin{array}{r}\text { Actual } \\
1994\end{array}$ & $\begin{array}{c}\text { Comparator } \\
\text { country }\end{array}$ & & & & \\
\hline & $(1)$ & (2) & (3) & (4) & (5) & (6) & (7) \\
\hline Agriculture & 820 & 328 & 130 & -492 & -690 & -492 & - \\
\hline Mining & 100 & 39 & 26 & -61 & -74 & -61 & - \\
\hline Manufacturing & 1408 & 889 & 998 & -519 & -410 & -410 & -109 \\
\hline Electricity & 130 & 108 & 39 & -22 & -91 & -22 & - \\
\hline Construction & 345 & 201 & 251 & -144 & -94 & -94 & -50 \\
\hline Trade & 555 & 578 & 687 & 23 & 132 & 23 & - \\
\hline Transportation & 380 & 315 & 229 & -65 & -151 & -65 & - \\
\hline Finance & 38 & 73 & 359 & 35 & 321 & 35 & - \\
\hline $\begin{array}{l}\text { Community } \\
\text { services }\end{array}$ & 1152 & 1221 & 1123 & 69 & -29 & - & 69 \\
\hline Unemployment & 24 & 568 & 471 & 544 & - & - & - \\
\hline Total & 4952 & 4320 & 4320 & -632 & | $1992 \mid$ & $|1202|$ & 228 \\
\hline
\end{tabular}




\section{TABLE A6 \\ Poland}

\begin{tabular}{|c|c|c|c|c|c|c|c|}
\hline & \multicolumn{3}{|c|}{ Labour Force } & \multirow{2}{*}{$\begin{array}{c}\text { Change in } \\
\text { employment } \\
1989-94 \\
(2)-(1)\end{array}$} & \multirow{2}{*}{$\begin{array}{c}\text { Employment } \\
\text { differential } \\
1989 \\
\text { (3)-(1) }\end{array}$} & \multirow[t]{2}{*}{ Convergent } & \multirow{2}{*}{$\begin{array}{c}\text { Non- } \\
\text { Convergent }\end{array}$} \\
\hline & $\begin{array}{c}\text { Actual } \\
1989\end{array}$ & $\begin{array}{r}\text { Actual } \\
1994 \\
\end{array}$ & $\begin{array}{c}\text { Comparator } \\
\text { country }\end{array}$ & & & & \\
\hline & $(1)$ & $(2)$ & (3) & (4) & (5) & $(6)$ & (7) \\
\hline Agriculture & 4557 & 3920 & 1510 & -637 & -3047 & -637 & - \\
\hline Mining & 578 & 394 & 70 & -184 & -508 & -184 & - \\
\hline Manufacturing & 4173 & 2970 & 3320 & -1203 & -853 & -853 & -350 \\
\hline Electricity & 182 & 276 & 123 & 94 & -59 & - & 94 \\
\hline Construction & 1321 & 839 & 1230 & -482 & -91 & -91 & -391 \\
\hline Trade & 1515 & 2137 & 2916 & 622 & 1401 & 622 & - \\
\hline Transportation & 1222 & 835 & 914 & -387 & -308 & -308 & -79 \\
\hline Finance & 172 & 241 & 966 & 69 & 794 & 69 & - \\
\hline $\begin{array}{l}\text { Community } \\
\text { services }\end{array}$ & 3282 & 3096 & 4058 & -236 & 776 & - & -236 \\
\hline Unemployment & - & 2910 & 2459 & 2910 & - & - & - \\
\hline Total & 17002 & 17618 & 17618 & 616 & | 7837 & | 2764 | & $|1150|$ \\
\hline
\end{tabular}




\section{TABLE A7 \\ Romania}

\begin{tabular}{|c|c|c|c|c|c|c|c|}
\hline & \multicolumn{3}{|c|}{ Labour Force } & \multirow{2}{*}{$\begin{array}{c}\text { Change in } \\
\text { employment } \\
\text { 1989-94 } \\
(2)-(1)\end{array}$} & \multirow{2}{*}{$\begin{array}{c}\text { Employment } \\
\text { differential } \\
1989 \\
(3)-(1) \\
\end{array}$} & \multirow[t]{2}{*}{ Convergent } & \multirow{2}{*}{$\begin{array}{c}\text { Non- } \\
\text { Convergent }\end{array}$} \\
\hline & $\begin{array}{c}\text { Actual } \\
1989 \\
\end{array}$ & $\begin{array}{r}\text { Actual } \\
1994 \\
\end{array}$ & $\begin{array}{c}\text { Comparator } \\
\text { country }\end{array}$ & & & & \\
\hline & $(1)$ & $(2)$ & (3) & (4) & $(5)$ & (6) & (7) \\
\hline Agriculture & 3056 & 3564 & 966 & 508 & -2090 & - & 508 \\
\hline Mining & 259 & 260 & 45 & 1 & -214 & - & 1 \\
\hline Manufacturing & 3613 & 2453 & 2123 & -1160 & -1490 & -1160 & - \\
\hline Electricity & 133 & 170 & 79 & 37 & -54 & - & 37 \\
\hline Construction & 767 & 561 & 786 & -206 & 19 & - & -206 \\
\hline Trade & 649 & 671 & 1865 & 22 & 1216 & 22 & - \\
\hline Transportation & 757 & 561 & 584 & -196 & -173 & -173 & -23 \\
\hline Finance & 35 & 60 & 618 & 25 & 583 & 25 & - \\
\hline $\begin{array}{l}\text { Community } \\
\text { services }\end{array}$ & 1677 & 1722 & 2595 & 45 & 918 & 45 & - \\
\hline Unemployment & - & 1224 & 1573 & 1224 & - & - & - \\
\hline Total & 10946 & 11246 & 11246 & 300 & 6757 & | $1425 \mid$ & |775 | \\
\hline
\end{tabular}




\section{TABLE A8 \\ Slovakia}

\begin{tabular}{|c|c|c|c|c|c|c|c|}
\hline & \multicolumn{3}{|c|}{ Labour Force } & \multirow{2}{*}{$\begin{array}{c}\text { Change in } \\
\text { employment } \\
\text { 1989-94 } \\
(2)-(1)\end{array}$} & \multirow{2}{*}{$\begin{array}{c}\text { Employment } \\
\text { differential } \\
1989 \\
(3)-(1)\end{array}$} & \multirow[t]{2}{*}{ Convergent } & \multirow{2}{*}{$\begin{array}{c}\text { Non- } \\
\text { Convergent }\end{array}$} \\
\hline & $\begin{array}{c}\text { Actual } \\
1989\end{array}$ & $\begin{array}{r}\text { Actual } \\
1994\end{array}$ & $\begin{array}{c}\text { Comparator } \\
\text { country }\end{array}$ & & & & \\
\hline & $(1)$ & $(2)$ & (3) & (4) & (5) & (6) & (7) \\
\hline Agriculture & 345 & 214 & 74 & -131 & -271 & -131 & - \\
\hline Mining & 25 & 34 & 15 & 9 & -10 & - & 9 \\
\hline Manufacturing & 801 & 564 & 570 & -237 & -231 & -231 & -6 \\
\hline Electricity & 41 & 48 & 22 & 7 & -19 & - & 7 \\
\hline Construction & 289 & 187 & 143 & -102 & -146 & -102 & - \\
\hline Trade & 278 & 258 & 393 & -20 & 115 & - & -20 \\
\hline Transportation & 161 & 163 & 131 & 2 & -30 & - & 2 \\
\hline Finance & 9 & 25 & 205 & 16 & 196 & 16 & - \\
\hline $\begin{array}{l}\text { Community } \\
\text { services }\end{array}$ & 549 & 610 & 642 & 61 & 93 & 61 & - \\
\hline Unemployment & - & 366 & 269 & 366 & - & - & - \\
\hline Total & 2498 & 2469 & 2469 & -29 & $|1111|$ & $|541|$ & $44 \mid$ \\
\hline
\end{tabular}




\section{TABLE A9 \\ Greece}

\begin{tabular}{|c|c|c|c|c|c|c|c|}
\hline & \multicolumn{3}{|c|}{ Labour Force } & \multirow{2}{*}{$\begin{array}{c}\text { Change in } \\
\text { employment } \\
1989-93 \\
(2)-(1)\end{array}$} & \multirow{2}{*}{$\begin{array}{c}\text { Employment } \\
\text { differential } \\
1989 \\
(3)-(1)\end{array}$} & \multirow[t]{2}{*}{ Convergent } & \multirow{2}{*}{$\begin{array}{c}\text { Non- } \\
\text { Convergent }\end{array}$} \\
\hline & $\begin{array}{c}\text { Actual } \\
1989 \\
\end{array}$ & $\begin{array}{r}\text { Actual } \\
1993 \\
\end{array}$ & $\begin{array}{c}\text { Comparator } \\
\text { country }\end{array}$ & & & & \\
\hline & $(1)$ & $(2)$ & (3) & (4) & (5) & (6) & (7) \\
\hline Agriculture & 930 & 794 & 354 & -136 & -576 & -136 & - \\
\hline Mining & 21 & 19 & 16 & -2 & -5 & -2 & - \\
\hline Manufacturing & 715 & 580 & 779 & -135 & 64 & - & -135 \\
\hline Electricity & 36 & 40 & 29 & 4 & -7 & - & 4 \\
\hline Construction & 239 & 261 & 288 & 22 & 49 & 22 & - \\
\hline Trade & 624 & 792 & 684 & 168 & 60 & 60 & 108 \\
\hline Transportation & 241 & 249 & 214 & 8 & -27 & - & 8 \\
\hline Finance & 169 & 221 & 227 & 52 & 58 & 52 & 3 \\
\hline $\begin{array}{l}\text { Community } \\
\text { services }\end{array}$ & 695 & 765 & 951 & 70 & 256 & 70 & - \\
\hline Unemployment & 290 & 398 & 577 & 108 & - & - & - \\
\hline Total & 3961 & 4118 & 4118 & 157 & | $1302 \mid$ & $|342|$ & $|258|$ \\
\hline
\end{tabular}

Source: OECD- Labour Force Statistics (1993) and authors' computations 


\section{TABLE A10 \\ Portugal}

\begin{tabular}{|c|c|c|c|c|c|c|c|}
\hline & \multicolumn{3}{|c|}{ Labour Force } & \multirow{2}{*}{\begin{tabular}{|c|} 
Change in \\
employment \\
$1989-93$ \\
$(2)-(1)$
\end{tabular}} & \multirow{2}{*}{$\begin{array}{c}\text { Employment } \\
\text { differential } \\
1989 \\
(3)-(1)\end{array}$} & \multirow[t]{2}{*}{ Convergent } & \multirow{2}{*}{$\begin{array}{c}\text { Non- } \\
\text { Convergent }\end{array}$} \\
\hline & $\begin{array}{c}\text { Actual } \\
1989 \\
\end{array}$ & $\begin{array}{r}\text { Actual } \\
1993 \\
\end{array}$ & $\begin{array}{c}\text { Comparator } \\
\text { country }\end{array}$ & & & & \\
\hline & $(1)$ & $(2)$ & $(3)$ & (4) & $(5)$ & (6) & (7) \\
\hline Agriculture & 829 & 505 & 410 & -324 & -419 & -324 & - \\
\hline Mining & 20 & 21 & 19 & 1 & -1 & - & 1 \\
\hline Manufacturing & 1107 & 1062 & 902 & -45 & -205 & -45 & - \\
\hline Electricity & 38 & 31 & 33 & -7 & -5 & -5 & -2 \\
\hline Construction & 384 & 362 & 334 & -22 & -50 & -22 & - \\
\hline Trade & 655 & 867 & 792 & 212 & 137 & 137 & 75 \\
\hline Transportation & 180 & 210 & 248 & 30 & 68 & 30 & - \\
\hline Finance & 154 & 310 & 263 & 156 & 109 & 109 & 47 \\
\hline $\begin{array}{l}\text { Community } \\
\text { services }\end{array}$ & 1009 & 1099 & 1102 & 90 & 93 & 90 & - \\
\hline Unemployment & 300 & 304 & 668 & 4 & - & - & - \\
\hline Total & 4677 & 4772 & 4772 & 95 & | $1087 \mid$ & $|762|$ & $|125|$ \\
\hline
\end{tabular}

Source: OECD- Labour Force Statistics (1993) and authors' computations 


\section{TABLE A11 \\ Spain}

\begin{tabular}{|c|c|c|c|c|c|c|c|}
\hline & \multicolumn{3}{|c|}{ Labour Force } & \multirow{2}{*}{\begin{tabular}{|c|} 
Change in \\
employment \\
$1989-93$ \\
$(2)-(1)$ \\
\end{tabular}} & \multirow{2}{*}{$\begin{array}{c}\text { Employment } \\
\text { differential } \\
1989 \\
(3)-(1)\end{array}$} & \multirow[t]{2}{*}{ Restructuring } & \multirow{2}{*}{$\begin{array}{c}\text { Non- } \\
\text { Restructuring }\end{array}$} \\
\hline & $\begin{array}{c}\text { Actual } \\
1989\end{array}$ & $\begin{array}{r}\text { Actual } \\
1993 \\
\end{array}$ & $\begin{array}{c}\text { Comparator } \\
\text { country }\end{array}$ & & & & \\
\hline & $(1)$ & $(2)$ & (3) & (4) & (5) & (6) & (7) \\
\hline Agriculture & 1598 & 1198 & 1339 & -400 & -259 & -259 & -141 \\
\hline Mining & 77 & 58 & 62 & -19 & -15 & -15 & -4 \\
\hline Manufacturing & 2738 & 2404 & 2942 & -334 & 204 & - & -334 \\
\hline Electricity & 85 & 80 & 109 & -5 & 24 & - & -5 \\
\hline Construction & 1135 & 1090 & 1090 & -45 & -45 & -45 & - \\
\hline Trade & 2467 & 2485 & 2584 & 18 & 117 & 18 & - \\
\hline Transportation & 711 & 700 & 809 & -11 & 98 & - & -11 \\
\hline Finance & 640 & 767 & 856 & 127 & 216 & 127 & - \\
\hline $\begin{array}{l}\text { Community } \\
\text { services }\end{array}$ & 2809 & 3044 & 3595 & 235 & 786 & 235 & - \\
\hline Unemployment & 2900 & 3738 & 2179 & 838 & - & - & - \\
\hline Total & 15160 & 15564 & 15564 & 404 & $|1764|$ & | $699 \mid$ & $495 \mid$ \\
\hline
\end{tabular}

Source: OECD- Labour Force Statistics (1993) and authors' computations 


\section{FIGURE 1}

Unemployment and new job creation in transitional economies

Source: Tables 4 and 5 


\section{REFERENCES}

Aghion, P. and Blanchard, O. (1994), 'On the Speed of Transition in Central Europe', NBER Macroeconomics Annual.

Beleva, I., Jackman, R. and Nenova, M. (1995), 'The Labour Market in Bulgaria', in Commander and Coricelli (eds), op cit.

Blanchard, O. (1991), 'Notes on the Speed of Transition, Unemployment and Growth in Poland', mimeo.

Boeri, T. (1993), 'Labour Market Flows and the Persistence of Unemployment in Central and Eastern Europe', paper presented at OECD Workshop on 'The Persistence of Unemployment in Central and Eastern European Countries', Paris.

Boeri, T. (1994), “'Transitional' Unemployment', Economics of Transition, Vol.2, No.1, pp.1-25.

Boeri, T. and Burda, M. (forthcoming), 'Active Labour Market Policies, Job Matching and the Czech Miracle', European Economic Review.

Commander, S. and Coricelli, F., (eds), (1995), Unemployment, Restructuring and the Labour Market in East Europe and Russia, The World Bank, Washington, D.C.

Commander, S., McHale J. and Yemtsov, R. (1995), 'Russia' in Commander, S. and Coricelli, F. (eds.), op cit.

Earle, J.S. and Oprescu, G. (1994), 'Employment and Wage Determination, Unemployment and Labour Policies in Romania' in Commander and Coricelli (eds), op cit. 
Ham, J., Svejnar, J. and Terrell, K. (1995), 'The Czech and Slovak Labour Markets during the Transition' in Commander and Coricelli (eds), op cit.

Hare, P. and Hughes, G. (1992), 'Industrial Policy and Restructuring in Eastern Europe', Oxford Review of Economic Policy, Vol 8, No.1.

Jackman, R., Layard, R. and Scott, A. (1992), 'Unemployment in Eastern Europe', paper presented to NBER Conference, Cambridge, MA, February, 1992.

Jackman, R. and Rutkowski, M. (1994), 'Labour Markets: Wages and Employment' in N. Barr (ed), Labour Markets and Social Policy in Central and Eastern Europe: The Transition and Beyond, Oxford University Press for the World Bank, September.

Kollo, J. (1993), 'Unemployment and Unemployment Related Expenditures', Blue Ribbon Commission, Budapest.

McAuley, A. (1991), 'The Economic Transition in Eastern Europe: Employment, Income Distribution and the Social Safety Net', Oxford Review of Economic Policy, Vol.7(4), pp.93-105.

Mroczkowski, T. (1996), 'Informal Employment in the Transition Economy of Poland', Department of International Business, Washington, D.C.

OECD (forthcoming), 'What can we learn from the experience of transition countries with labour market policies?', Proceedings of technical workshop, Vienna, Nov 30-Dec 2, 1995.

Puhani, P and Steiner, V. (1996), 'Public Works for Poland? Active Labour Market Policies during the Transition', ZEW Labour 
Economics, Human Resources and Social Policy series, Discussion Paper No. 96-01, Mannheim, Germany.

Scarpetta, S. and Reutersward, A. (1994), 'Unemployment Benefit Systems and Active Labour Market Policies in Central and Eastern Europe: An Overview' in T. Boeri (ed), Unemployment in Transition Countries: Transient or Persistent?, OECD, Paris.

Vercenik, J. (1993), 'Czechoslovakia and the Czech Republic in 1990 - 93', Institute of Sociology, Academy of Sciences, Prague.

World Bank (1995), 'Workers in an Integrating World', World Development Report 1995. 